\title{
PERANAN PAJAK PROGRESIF KENDARAAN BERMOTOR DALAM TRANPORTASI KOTA BESAR
}

\author{
Hanggoro Pamungkas \\ Jurusan Akuntansi, Fakultas Ekonomi dan Komunikasi, BINUS University \\ Jln. K.H. Syahdan No. 9, Palmerah, Jakarta Barat 11480 \\ hanggoro_p@hotmail.com
}

\begin{abstract}
Transportation in big cities has phenomenal progressrecenly, with growths in automotive vehicles number over the infrastructure and roads length. Jakarta as the bigest cityand the capital of Indonesia has stronger economics, wider areas, more automotive vehicles number, and its populations. Data in the survey, literatures, and analysis over three years in Jakarta, has shown fantastic changes of automotive vehicles number growth composition. Two wheels automotive vehicles growth and number are in the top rank from other categories. Survey of Jakarta has shown economics growth that has increased prosperity of some population group, caused to automotive ownership taxes increase. In the contrary it has also negative effects in inefficiency and national social cost caused from traffic problem. It is suggested that options possibility to overcome from traffic or transportation problem in Jakarta, especially related to traffic management or automotive vehicle ownership management.
\end{abstract}

Keywords: transportation, traffic jam, vehicles tax

\begin{abstract}
ABSTRAK
Transportasikota besar dewasa ini berkembang fenomenal dengan pertumbuhan jumlah kendaraan melebihi pertambahan jumlahdan kualitas jalan. Sebagai ibu kota Negara, Jakarta merupakan kota terbesar dibanding yang lain, dari kekuatan ekonomi, luas wilayah, jumlah kendaraan, dan penduduknya. Pengamatan, kepustakaan, dan analisa penelitian data tiga tahun di Jakarta, menunjukkan perubahan komposisi pertumbuhan jumlah kendaraan yang fantastis.Kendaraan bermotor roda dua menempati tingkat pertumbuhan tertinggi dibanding kelompok lainnya. Penelitian menunjukkan pertumbuhan ekonomi yang menaikkan kesejahteraan kelompok penduduk tertentu,dalam pertambahan kepemilikan kendaraan bermotor, yang menaikkan Penerimaan Pajak Kendaraan Bermotor tetapi juga berdampak negatif(inefisiensi atau kenaikan biaya sosial) karena kemacetan yang terjadi. Penulis menyimpulkan opsi pilihan pemecahan masalah penanggulangan masalah transportasi kotabesar, terkait Kebijakan Manajemen Tansportasi atau Manajemen Pajak Kendaraan Bermotor.
\end{abstract}

Kata kunci: transportasi, kemacetan jalan, pajak kendaraan bermotor 


\section{PENDAHULUAN}

Transportasi di beberapa kota besar di beberapa negara berkembang lainnya termasuk khususnya di Jakarta, sedang diuji bagaimana pemerintah melakukan manajemen transportasi dalam menanggulangi dan mengantisivasi kondisi pertumbuhan jumlah kendaraan, jumlah pengguna kendaraan dan prasarana dan sarana penunjangnya, dalam rangka memberikan pelayanan terbaikuntuk masyarakat. Pada gilirannya tujuan pemerintah adalah untuk memberikan dan menciptakan keadaan yang terbaik, menekan inefisiensi karena kemacetan dan inefisiensi lain dalam segala aspeknya.

Manajemen transportasi di kota besar dewasa ini sudah dirasakan merugikan banyak pihak dengan kemacetan yang mengarah inefisiensi dan tingginya social cost amat besar, jika tidak ditanggulangi dengan tepat dan cepat. Salah satu alat untuk mengurai masalah transportasi khususnya kemacetan jalan mungkin bisa memanfaatkan kebijakan yang dilandasi 'fungsi mengatur'dalam perpajakan khususnya pajak daerah.

Menurut data Dinas Perhubungan DKI, diketahui data terakhir terdapat kepemilikan kendaraan bermotor roda empat atau lebih di DKI Jakarta Raya adalah Mobil pribadi $=2.021 .168$, Truk = 536.156, dan Angkutan umum = 308.377, atau total sekitar hampir mendekati 3.000.000 (ini belum termasuk kendaraan bermotor roda dua yang ternyata berlipat daritotal angka tersebut).

Dalam mewujudkan pembangunan pemerintah perlu dana pembiayaan besar dari pinjaman, sektor migas dan sektor non-migas. Sektor terpentingdalam penerimaan pemerintah adalah pajak. Definisi pajak, menurut Soemitro (dalam Mardiasmo, 2008), diulas bahwa pajak adalah "iuran rakyat kepada kas negara sesuai dengan perundang-undangan yang berlaku (memaksa), tanpa kontraprestasi (timbal balik), yang digunakan untuk pengeluaran umum” (p. 1). Pajak dibagi dua bagian menurut lembaga/instansi yang memungut, yaitu pajak pusat dan pajak daerah.Selain Pajak Pusat, Pajak daerah adalah yang dikelola dan dipungut pemerintah Propinsi atau Kabupaten/Kota (misalnya Pajak Provinsi yang terkait Kendaraan Bermotor).

Dewasa ini sebagian besar penerimaan pemerintah daerah dalam Anggaran Pendapatan dan Belanja Daerah (APBD), penerimaan dari sektor pajak daerah termasuk pajak terkait kendaraan bermotor merupakan penyumbang terbesar dalam APBD.Dari Anggaran Pendapatan dan Belanja Daerah (APBD) DKI Jakarta kurun 2007-2009, penerimaan dari sektor pajak daerah adalah 86,43\%, 103,15\%, dan 99,36\%. Data terakhir realisasi penerimaan Pajak Kendaraan Bermotor / PKB DKI pada 2010 adalah sekitar Rp3,11 triliun, bahkan target untuk 2011 sudah dicanangkan dengan rencana sekitar Rp3,7 triliun.

Dalam Undang-undang Nomor 28 Tahun 2007 tentang Perubahan Ketiga Atas Undangundang Nomor 6 Tahun 1983 Tentang Ketentuan Umum dan Tata Cara Perpajakan (Republik Indonesia, 2007), mengartikan pajak sebagai "kontribusi wajib kepada negara yang terutang oleh orang pribadi atau badan yang bersifat memaksa berdasarkan Undang-undang, dengan tidak mendapatkan imbalan secara langsung dan digunakan untuk keperluan negara bagi sebesar-besarnya kemakmuran rakyat", Seluruh penduduknya berhak merasakan hasil dari pembangunan tersebut secara meyeluruh.

Pemerintah mengupayakan pemerataan pembangunan melalui program desentralisasi dengan hak otonomi daerah sejak Januari 2001, setiap pemerintah daerah di Indonesia harus memiliki cara memperoleh pendapatan daerahnya dengan maksimal. Otonomi daerah yang luas dan bertanggung jawab memberi kebebasan kepada pemerintah daerah untuk mengatur sendiri urusan pemerintahan dan kepentingan masyarakat sesuai potensi dan keanekaragaman wilayahnya agar terwujud kesejahteraan. Pembangunan daerah perlu dana cukup besar, salah satu sumber penerimaan daerah berasal dari Pendapatan Asli Daerah (PAD) seperti pajak daerah, retribusi daerah, laba Badan Usaha Milik Daerah (BUMD) dan PAD lainnya. 
Salah satu jenis pajak daerah yang erat terkait masalah transportasi adalah Pajak Kendaraan Bermotor (PKB) yaitu pajak yang dipungut atas kepemilikan atau penguasaan kendaraan bermotor.PKB merupakan pajak daerah yang paling potensial (sekitar 30\% - 40\%) dari total keseluruhan Pajak Daerah (sampling data penelitian pada Kantor Bersama Samsat Wilayah Jakarta Selatan).Kantor Sistem Administrasi Manunggal Dibawah Satu Atap (Samsat)adalah sistem pemungutan PKB terkait pengesahan Surat Tanda Nomor Kendaraan (STNK), perpanjangan STNK dan pendaftaran STNK, termasuk pungutan lain seperti Asuransi Jasa Raharja.

Sampling pengamatan dilandasimakin banyaknya kendaraan bermotor di DKI Jakarta Raya, seharusnya akan berdampak positif ke penerimaan pendapatan daerah terutama PKB semoga bisa memberikan kontribusi untuk semua stakeholders terkait. Pembahasan peranan PKB terhadap peningkatan PAD secara keseluruhan, dari rencana dan realisasi penerimaan PKB, realisasi penerimaan Pajak Daerah dan PAD.

Evaluasi pemungutan PKB dalam meningkatkan PAD memakai data realisasi penerimaan pelaksanaan Belum Daftar Ulang (BDU) dan Samsat Keliling (Samling), periode 2008-2009 karena baru mulai beroperasi 2008.Sedang untuk pelayanan khusus/modern Samsat (drive-thru) hanya 2009, karena layanannya baru mulai 2009.

Darwin (2010) mengulas batasan atau definisi berbagai jenis pajak dan para ahli atau pemerhati pajak yang menyajikan definisi sesuai kemampuan pemahaman dan pemikirannya. Dari beberapa definisi, disimpulkan unsur yang melekat pada pengertian pajak seperti: (1) Iuran dari rakyat keNegara, negara berhak memungut pajak (uang bukan barang); (2) Sesuai UU 28/2007 tentang perubahan ketiga atas UU 6/1983 tentang Ketentuan Umum Dan Tata Cara Perpajakan, pajak dipungut berdasarkan UU dan aturan pelaksanaannya; (3) tanpa jasa timbal /kontraprestasi dari Negara yang langsung dapat ditunjuk, dalam pajak tak dapat ditunjukkan ada kontraprestasi individual oleh pemerintah; (4) untuk membiayai rumah tangga negara,yakni pengeluaran yang bermanfaat bagi masyarakat luas.

Berbagai teori menguraikan Pajak Negara,selain berfungsi penerimaan (budgetair) sebagai sumber dana pemerintahan untuk membiayai pengeluarannya, juga fungsi Mengatur (Regulerend), alat mengatur atau melaksanakan kebijakan pemerintah di bidang sosial ekonomi, seperti pajak yang tinggi pada minuman keras dan barang mewah, dan pajak ekspor 0\% untuk mendorong ekspor produk Indonesia di pasar dunia.

Dalam tiga pengelompokan pajak, yakni menurut golongannya (Pajak Langsung \& Tidak Langsung), sifatnya (Pajak Subjektif \& Pajak Obyektif), serta dampak pemungutnya, yakni: (1) Pajak Pusat, oleh pemerintah pusat untuk biaya rumah tangga Negara, seperti Pajak Penghasilan, Pajak Pertambahan Nilai dan Pajak Penjualan atas Barang Mewah; dan (2) Pajak Daerah, olehpemerintah daerah untuk biaya rumah tangga daerah, terdiri Pajak Propinsi seperti PKB dan Pajak Bahan Bakar Kendaraan Bermotor, dan Pajak Kabupaten/Kota seperti Pajak Hotel, Pajak Restoran, dan Pajak Hiburan.

Pasal 1 Peraturan Pemerintah RI 65/2001 tentang Pajak Daerah (Republik Indonesia, 2001) mengartikan sebagai "iuran wajib yang dilakukan daerah kepada orang pribadi atau badan tanpa imbalan langsung yang seimbang, yang dapat dipaksakan sesuai peraturan perundang-undangan, untuk biaya penyelenggaraan pemerintah daerah dan pembangunan daerah.” Pajak daerah ditetapkan dengan peraturan daerah (Perda), pemungutannya dilakukan pemerintah daerah dan hasilnya untuk biaya pengeluaran pemerintah daerah dalam penyelenggaraan pemerintahan dan pembangunan daerahnya.Pemerintah daerah di Indonesia adalah provinsi dan kabupaten/kotadengan wewenang melaksanakan otonomi daerah termasuk pengelolaan pajak provinsi dan pajak kabupaten/kota. 
Dalam UU 28/2009 (perubahan atas UU 34/2000 dan UU 18/1997), tentang Pajak Daerah dan Retribusi Daerah (Republik Indonesia, 2009), dengan beberapa perubahan, seperti jenis kelompok Pajak Propinsi seperti PKB, Bea Balik Nama Kendaraan Bermotor, Pajak Bahan Bakar Kendaraan Bermotor, Pajak Air Permukaan, dan Pajak Rokok. Sedang Pajak Kabupaten/Kota seperti Pajak Hotel, Pajak Restoran, Pajak Hiburan, Pajak Reklame, Pajak Penerangan Jalan, Pajak Mineral Bukan Logam dan Batuan, Pajak Parkir, Pajak Air Tanah, Pajak Sarang Burung Walet, Pajak Bumi dan Bangunan Perdesaan dan Perkotaan, serta Bea Perolehan atas Hak dan Tanah Bangunan.

Tarif pajak ditentukan tarif tertinggi dan bervariasi, sebagai satu unsur perhitungan pajak yang menentukan besar pajak terutang yang harus dibayar WP, yang diberlakukan pada tiap jenis pajak daerah memegang peranan penting, termasuk pajak-pajak pada Tabel 1.

Tabel 1. Tarif Pajak yang Berkaitan dengan Kendaraan

\begin{tabular}{ll}
\hline Pajak Kendaraan Bermotor dan Kendaraan di Atas Air & $5 \%$ \\
Bea Balik Nama Kendaraan Bermotor dan Kendaraan di Atas Air & $10 \%$ \\
Pajak Bahan Bakar Kendaraan Bermotor & $5 \%$ \\
Pajak Parkir & $20 \%$ \\
\hline
\end{tabular}

\section{Kajian Teori}

Pertama penulis perlu mengulas segala sesuatu tentang PKB dan segala kaitannya dengan PAD atau APBD, dan perkembangan terakhir aspek perkembangan ekonomi dan kesejahteraan warga hingga dampaknya kepada system transportasi dalam suatu daerah. Untuk lebih kuat perlu didukung data kuantitatif, maka penulis mencari data kurun 2007-2009, dan melakukan analisa kemungkinan keterkaitan atas setiap data terkait otonomi daerah, pajak daerah, pajak kendaraan bermotor, dan transportasi.

Masalah sedikit kegamangan dalam persiapan pelaksanaan otonomi daerah di Indonesia diwarnai adanya keraguan terhadap kemampuan setiap daerah menggali potensi sumber dana untuk membiayai kegiatannya. Dengan otonomi daerah, daerah didorong untuk meningkatkan PAD, banyak daerah yang memikirkan bagaimana meningkatkan tarif pajak daerah dan retribusi daerah serta memikirkan untuk menciptakan objek pajak daerah dan retribusi daerah yang baru. Sebagai langkah antisipasi keraguan tersebut, pemerintah menempuh kebijakan memberi kewenangan yang lebih besar ke daerah untuk menggali dana sebagai sumber pembiayaan atas penyediaan public service (pelayanan umum) kepada masyarakat. Penggalian potensi dana tersebut termasuk melalui kegiatan pemungutan pajak daerah dan retribusi daerah.

Dalam UU 28/2009 tentang Pajak Daerah dan Retribusi Daerah (Republik Indonesia, 2009), antara lain memberi kewenangan yang lebih besar melalui perluasan jenis dan cakupan pajak daerah dan retribusi daerah, dan pemberian fleksibilitas bagi daerah untuk memungut jenis pajak daerah dan retribusi daerah. Peranan pajak daerah dan retribusi daerah sebagai sumber pendapatan daerah yang utama disamping dana perimbangan yang diperoleh dari hasil eksploitasi sumberdaya alam akan sangat menentukan kekuatan dari Anggaran Pendapatan dan Belanja Daerah (APBD).

Menurut Davey (dalam Darwin, 2010) secara umum sumber pendapatan daerah terutama adalah dari pajak, baru disusul retribusi, perusahaan (BUMD), dan alokasi dari pemerintah pusat terdiri anggaran pusat (votes) dan bantuan pusat (grants), bagi hasil pajak, pinjaman dan penyertaan modal. 


\section{Pajak Kendaraan Bermotor (PKB)}

PKB menurut Peraturan Daerah Provinsi DKI Jakarta Nomor 4/2003 tentang Pajak Kendaraan Bermotor (Pasal 1) adalah pajak atas kepemilikan atau penguasaan kendaraan bermotor (semua kendaraan beroda dua keatas dan gandengannya yang dipakai di semua jenis jalan darat dan digerakkan peralatan teknik / motor atau peralatan lain, termasuk alat-alat besar yang bergerak). Alat berat dan alat besar yang bergerak adalah alat yang dapat bergerak/berpindah tempat dan tidak melekat secara permanen. Apabila alat berat tersebut hanya dipakai disekitar perkebunan, pertambangan dan tempat lain yang bukan jalan umum maka alat berat tersebut tidak terkena pajak. Kendaraan militer atau Polri menjadi tanggung jawab kementrian pertahanan dan keamanan negara.

Pemungutan PKB diatur Peraturan Gubernur 126/2008 tentang Perubahan Atas Peraturan Gubernur 90/2005 tentang Petunjuk Pelaksanaan Pemungutan PKB, sedang penerapan PKB pada suatu daerah provinsi didasarkan pada peraturan daerah provinsi sebagai landasan hukum operasional dalam teknis pelaksanaan pengenaan dan pemungutannya. Dilengkapi dengan keputusan gubernur yang mengatur PKB, sebagai aturan pelaksanaan Peraturan Daerah tentang PKB pada provinsi yang dimaksud.

Objek PKB adalah kepemilikan atau penguasaan kendaraan bermotor, termasuk kepemilikan atau penguasaan kendaraan bermotor yang dipakai di semua jenis jalan darat, seperti di kawasan bandara, pelabuhan laut, perkebunan, kehutanan, pertanian, pertambangan, industri, perdagangan, dan sarana olahraga dan rekreasi. Jalan darat disini diartikan prasarana transportasi darat meliputi segala bagian jalan, termasuk bangunan pelengkap dan perlengkapannya yang diperuntukkan bagi lalu lintas, pada permukaan tanah, di atas permukaan tanah, di bawah permukaan tanah atau air, serta di atas permukaan air, kecuali jalan kereta api, jalan lori, dan jalan kabel.

Pengertian kepemilikan atau penguasaan kendaraan bermotor meliputi kepemilikanatau penguasaan kendaraan bermotor yang terdaftar di daerah provinsi; kepemilikan atau penguasaan kendaraan bermotor di daerah provinsi selama jangka waktu tertentu, misalnya 90 hari berturut-turut; alat-alat berat dan alat-alat besar (termasuk forklif, bulldozer, tracktor, wheel loader, log loader, skyder, shovel, motor grader, excavator, back hoe, vibrator,compactor, scraper); serta jenis kendaraan darat lain seperti kereta gandeng.

Tidak semua kepemilikan atau penguasaan kendaraan bermotor dikenakan pajak, sebab ada beberapa pengecualian yakni kepemilikan atau penguasaan kendaraan bermotor oleh pihak-pihak tertentu (terutama pemerintah atau badan sosial), yaitu: (1) kepemilikan atau penguasaan kendaraan bermotor oleh pemerintah pusat dan pemerintah daerah (milik BUMN dan BUMD tidak dikecualikan); (2) kepemilikan atau penguasaan kendaraan bermotor oleh kedutaan, konsulat, perwakilan negara asing, dan perwakilan lembaga internasional (asas timbal balik); (3) kepemilikan atau penguasaan kendaraan bermotor oleh subjek pajak lainnya yang diatur peraturan daerah; dan (4) kereta api.

Siahaan (2005) mengulas dasar pengenaan, tarif, dan cara perhitungan PKB dari perkalian dua unsur pokok, Nilai Jual Kendaraan Bermotor (NJKB), dan Bobot, yang mencerminkan secara relatif kadar kerusakan jalan umum dan pencemaran lingkungan yang diakibatkan. Sedang NJKB adalah harga pasaran umum suatu kendaraan bermotor, jika harganya tidak diketahui, NJKP ditentukan dari beberapa faktor, yaitu: isi silinder, penggunaan kendaraan bermotor, jenis kendaraan bermotor, merk kendaraan bermotor, tahun pembuatan kendaraan bermotor, berat total kendaraan bermotor dan banyaknya penumpang yang diizinkan, dan dokumen impor untuk jenis kendaraan bermotor tertentu.

Bobot yang dihitung dari beberapa faktor, pertama tekanan gandar (jumlah sumbu/as, roda, dan berat kendaraan bermotor), kedua bahan bakar kendaraan bermotor (solar, bensin, gas, listrik atau tenaga surya), dan ketiga jenis/tahun penggunaan, dan ciri dari mesin kendaraan bermotor. 
Bobot dinyatakan koefisien tertentu, jika nilainya satu berarti kerusakan jalan dan pencemaran lingkungan oleh kendaraan bermotor tersebut dianggap masih dalam batas toleransi. Koefisien lebih besar dari satu berarti kendaraan bermotor tersebut berpengaruh lebihburuk atas kerusakan jalan dan pencemaran lingkungan, misalnya: (1) Pada 2002 Menteri Dalam Negeri menetapkan NJKB mobil Mercedes Benz C.180, buatan $2000=$ Rp290.000.000 dengan bobot 1,0 $\rightarrow$ maka dasar pengenaan pajaknya = Rp290.000.000 x 1,0 = Rp290.000.000; (2) Pada 2002 Menteri Dalam Negeri menetapkan NJKB kendaraan bukan umum Truk Isuzu CXZ-385/515-R diesel, buatan $2000=$ Rp125.100.000 (bobot 1,3) $\rightarrow$ maka dasar pengenaan pajaknya= Rp125.100.000 x 1,3 = Rp162.630.000.

Data penelitiannya dalam kurun 2007-2009 maka tarif pajaknya sesuai Peraturan Daerah 4/2003, dalam Pasal 6 tentang PKB. Tarifnya dibagi tiga kelompok: kendaraan non umum $=1,5 \%$, kendaraan umum $=1 \%$, dan kendaraan alat berat $=0,5 \%$. Namun dengan UU 28/2009 Pasal 6, tarif PKB (progresif) menjadi empat kelompok sesuai jenis penguasaan kendaraan bermotor, yaitu: (1) kepemilikan kendaraan bermotor pertama paling rendah $=1,5 \%$; (2) kepemilikan kendaraan bermotor kedua dan seterusnya, tarif dapat ditetapkan progresif paling rendah $=2 \%$ dan paling tinggi $=10 \%$; (3) angkutan umum, ambulans, pemadam kebakaran, sosial dan keagamaan, pemerintah/TNI/POLRI, Pemerintah Daerah, dan kendaraan lain yang ditetapkan peraturan daerah minimal $=0,5 \%$ dan maksimal $=1 \%$; dan (4) alat berat dan alat besar ditetapkan minimal $=0,1 \%$ dan maksimal $=0,2 \%$.

Pemerintah DKI Jakarta Raya memberlakukan tarif progresif PKB mulai 1 Januari 2011, untuk kendaraan milik pribadi, milik badan hukum atau kendaraan operasional perusahaan. Namun Dinas Pelayanan Pajak Provinsi DKI Jakarta Raya menetapkan tarif paling tinggi untuk kendaraan keempat dan seterusnya $=4 \%$. Ini masih relatif rendah dibanding ketentuan dalam UU 28/2009 tentang Pajak Daerah dan Retribusi Daerah (tarif tertinggi $=10 \%$ ). Namun setiap kota dan daerah di Indonesia dapat menentukan besarnya tarif berdasarkan potensi daerahnya. Tarif progresif ini diberlakukan sebagai opsi guna mengatasi kemacetan di Jakarta.Besarnya pokok PKB terutang dihitung dengan mengalikan tarif pajak dengan dasar pengenaan pajak, maka:

PKB Terutang $=$ Tarif $\mathrm{x}$ Dasar Pengenaan Pajak $=$ Tarif $\mathrm{x}(\mathrm{NJKB} \times \mathrm{x}$ Bobot $)$

Tarif: 1,5\% (KB bukan umum), 1\% (KB umum), dan 0,5\% (KB alat berat)

Penentuan Nilai jual: Diambil dari Pergub / Peraturan Ka. Dinas (SK Kadin)

Bobot: a. 1,0 (KB), b. 1,3 (KB truck), dan c. 1,0 (KB alat berat)

Contoh perhitungan PKBSedan Honda New City tipe IDSI 1.5, manual (MT),buatan 2005, ditetapkan pada 1 juli 2010:

$\mathrm{PKB}=$ Tarif $\mathrm{x}$ Dasar pengenaan pajak $=$ Tarif $\mathrm{x}($ Bobot $\mathrm{x}$ Nilai Jual $)$

- Tarif: Pajak sedan $=1,5 \%$, Bobot sedan $=1$ (satu), dan

- Nilai jual: KB = 1.5 manual (MT) buatan 2005 sesuai Pergub Provinsi

DKI Jakarta Raya 166/2009 tentang Perhitungan Dasar Pengenaan

PKB dan Bea Balik Nama Kendaraan Bermotor = Rp132.000.000

Maka PKB Sedan Honda New City tipe IDSI 1.5 manual (MT) buatan 2005

$=1,5 \% \times(1 \times$ Rp.132.000.000 $)=$ Rp1.980.000

\section{Bagi Hasil dan Biaya Pemungutan PKB}

Siahaan (2005) mengulas hasil penerimaan PKB merupakan pendapatan daerah yang harus disetorkan seluruhnya ke kas daerah provinsi.Hasil penerimaan PKB sebagian diperuntukan bagi daerah kabupaten/kota di wilayah provinsi tempat pemungutan PKB. Pembagian hasil penerimaan PKB ditetapkan dalam peraturan daerah provinsi, dengan perimbangan maksimal $70 \%$ untuk provinsi dan minimal 30\% untuk kabupaten/kota. 
Sesuai Keputusan Menteri Dalam Negeri 35/2002 tentang Pedoman Alokasi Biaya Pemungutan Pajak Daerah, ditetapkan alokasi biaya pemungutan PKB (untuk aparat pelaksana pemungutan dan aparat penunjang kegiatan pemungutan), terdiri dari $70 \%$ untuk aparat pelaksana pemungutan dan 30\% untuk aparat penunjang.

Peraturan Daerah Provinsi DKI Jakarta 4/2002 tentang Ketentuan Umum Pajak Daerah dan Peraturan Gubernur 90/2005 yang diperbaharui dengan Peraturan Gubernur 126/2008 tentang Petunjuk Pelaksanaan Pemungutan PKB, menetapkan petunjuk pelaksanaan pemungutan PKB untuk meningkatkan daya guna dan hasil guna dalam pemungutan PKB. Sistem pemungutan pajak dibagi tiga, yaitu dibayar sendiri oleh WP, ditetapkan oleh Gubernur, atau dipungut oleh pemungut pajak.

Sejak pendirian Samsat Wilayah Jakarta Selatan dan perkembangannya, awalnya volume pendaftaran kendaraan bermotor relatif cukup normal, sehingga Samsat Wilayah Jakarta Selatan dirasa cukup untuk melayani WP di lima wilayah DKI (Jakarta Selatan, Timur, Utara, Barat, dan Jakarta Pusat). Dalam pertumbuhan ekonomi, jumlah kendaraan di DKI Jakarta meningkat pesat, sehingga pelayanan pendaftaran kendaraan bermotor tidak cukup dilayani Kantor Samsat DKI Jakarta Selatan. Dalam upaya peningkatan pelayanan WP telah dibentuk Samsat mobil keliling (2008), dan juga Gerai Samsat dipusat perbelanjaan, serta mulai 2009 dimulai pelayanan drive-thru, guna lebih mempermudah pelayanan terkait kendaraan bermotor.

Dengan dibentuknya samsat-samsat tersebut, pendapatan daerah dari PKB meningkat signifikan tiap tahun, bahkan melampaui target PKB yang ditetapkan. Sebagai pengembangan fungsi lalu lintas dibidang registrasi dan identifikasi kendaran bermotor, Samsat Jakarta Selatan ditanganiorgan Kepolisian, Pemerintah Daerah dan Jasa Raharja sesuai tugastanggung jawabnya, bertanggung jawab menciptakan pelayanan yang baik kepada WP. Unsurkepolisian malaksanakan administrasi registrasi dan identifikasi kendaraan bermotor. Pemda dalam administrasi penerimaan pajak daerah dari PKB, dan Jasa Raharja untuk administrasi penerimaan Sumbangan Wajib Dana Kecelakaan Lalu Lintas Jalan Raya (SWDKLLJ) dengan baik dan benar.

Kantor Perbendaharaan dan Kas Daerah Provinsi DKI Jakarta berfungsi menerima dan menyimpan serta mengeluarkan keuangan Pemerintah Daerah yang tertuang dalam Keputusan Menteri Dalam Negeri, maka Kantor Samsat yang menginduk pada Kantor Perbendaharaan dan Kas Daerah Pronvinsi DKI Jakarta, hanya mempunyai fungsi menerima dan melaporkan serta mempertanggung jawabkan penerimaan pada sektor Pajak Kendaraan Bermotor dan Bea Balik Nama.

Tugas Kantor Samsat tertuang dalam Peraturan Gubernur 19/2005, Peraturan Daerah 3/2001, Surat Keputusan bersama Menhankam INS/03/M/X/1999, Mendagri 29/1999, Menkeu 6/IMK.014/1999, Kep. Ka. KPKD Prov.DKI Jakarta 1176/2007 Tentang SOP Penerimaan Daerah Pada KPKD Provinsi DKI Jakarta.Dalam pelaksanaannya kantor Samsat melibatkan Polri untuk dapat membantu pengawasan dan pengecekan Surat Tanda Nomor Kendaraan (STNK) di jalan, seperti razia STNK yang telah habis masa berlakunya atau telah jatuh tempo masa pajaknya bila ketahuan, WP akan terkena sanksi dan harus segera membayar pajaknya.

\section{METODE}

Penelitian ini berdasarkan metode pengamatan, kepustakaan, dan analisa penelitian data selama tiga tahun di Jakarta. 


\section{HASIL DAN PEMBAHASAN}

Untuk mengetahui peranan PKB terhadap PAD perlu analisis pertumbuhan PAD Propinsi DKI Jakarta Raya dengan sampling data tiga tahun secara seri kurun 2007-2009. Walau sampling tersebut kurun waktunya pendek tetapi terkendala masalah administrasi penyimpanan data, perbedaan kebijakan yang relatif berubah amat cepat. Hal khusus yang menjadi perhatian adalah adanya krisis ekonomi dan krisis keuangan jilid kedua pada kurun waktu data yang dianalisis tersebut.

Keadaan PKB 2009 ternyata terkait pertumbuhan PAD dibanding masa sebelumnya. Perkembangan penerimaan PKB dalam periode sama juga tumbuh meningkat searah dari tahun ke tahun, kecuali pada 2009 (bisa terkait faktor ekstern: ekonomi makro/nasional - ekses ekonomi global). Pertumbuhan ekonomi nasional yang positif tiga tahun tersebut, tentu mendorong penerimaan PKB terutama di kota besar seperti DKI Jakarta.

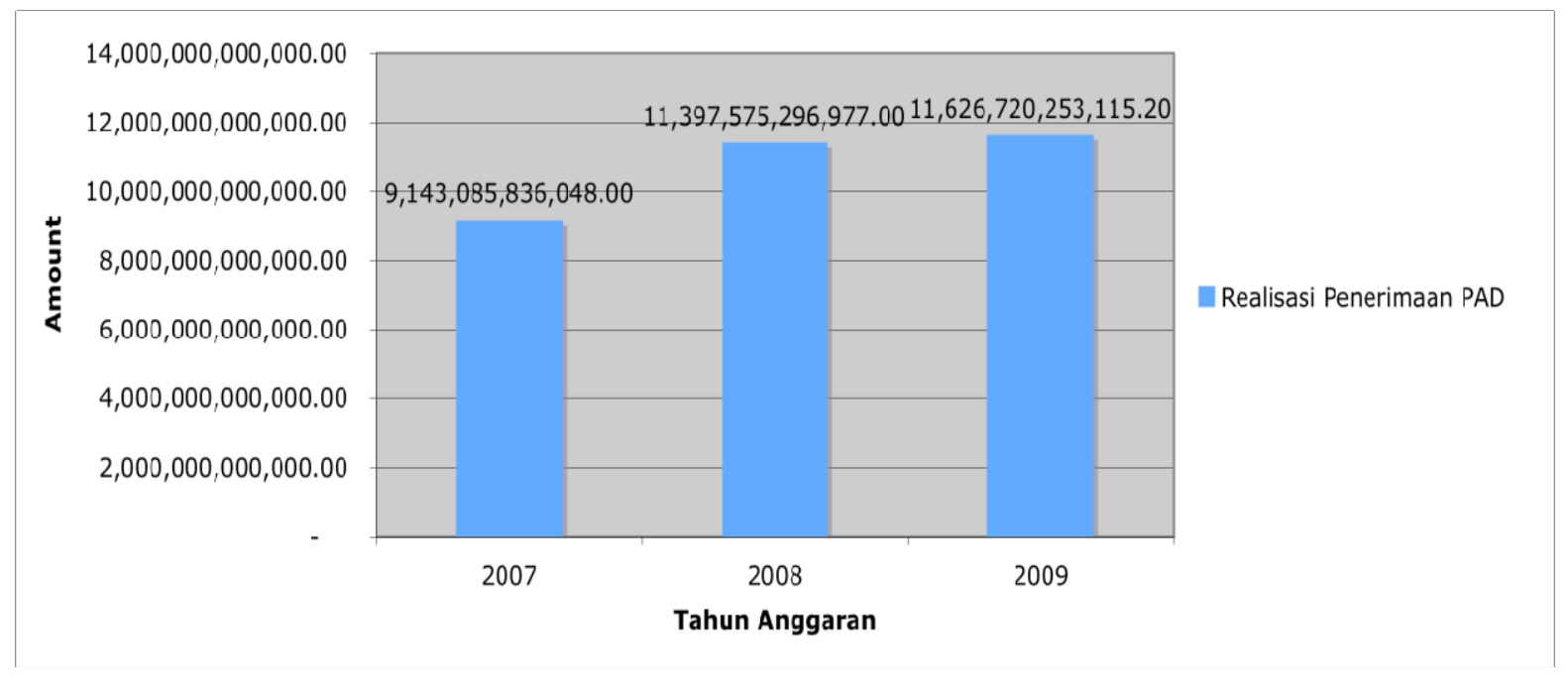

Gambar 1. Realisasi PAD Jakarta (2007-2009)

Tabel 2. Pertumbuhan PAD Jakarta(2007-2009)

\begin{tabular}{|c|c|c|c|}
\hline & Realisasi Penerimaan PAD & Pertumbuhan (Rp) & $(\%)$ \\
\hline 2007 & $9,143,085,836,048.00$ & - & - \\
\hline 2008 & $11,397,575,296,977.00$ & 2,254,489,460,929.00 & 24.66 \\
\hline \multirow[t]{2}{*}{2009} & $11,626,720,253,115.20$ & $229,144,956,138.20$ & 2.01 \\
\hline & & Rata-rata & 13.33 \\
\hline
\end{tabular}

Pembukaan impor mobil keadaan jadi (built up), dan banyaknya varian, tipe, atau model terus yang dilengkapi kemajuan teknologikomputer, sangat menggoda para pencinta kendaraan bermotor langka atau kelompok penduduk yang memiliki kemampuan meningkat dari memiliki motor bergeser ke pemilikan mobil. Adanya pemasukan motor mewah untuk hobby atau olah raga tertentu, jelas ikut perperan dalam pertambahan PKB. Semua faktor pendukungdiatas dengan langsung atau otomatis dapat mendorong bertumbuhnya hasil penerimaan PKB secara keseluruhan. 


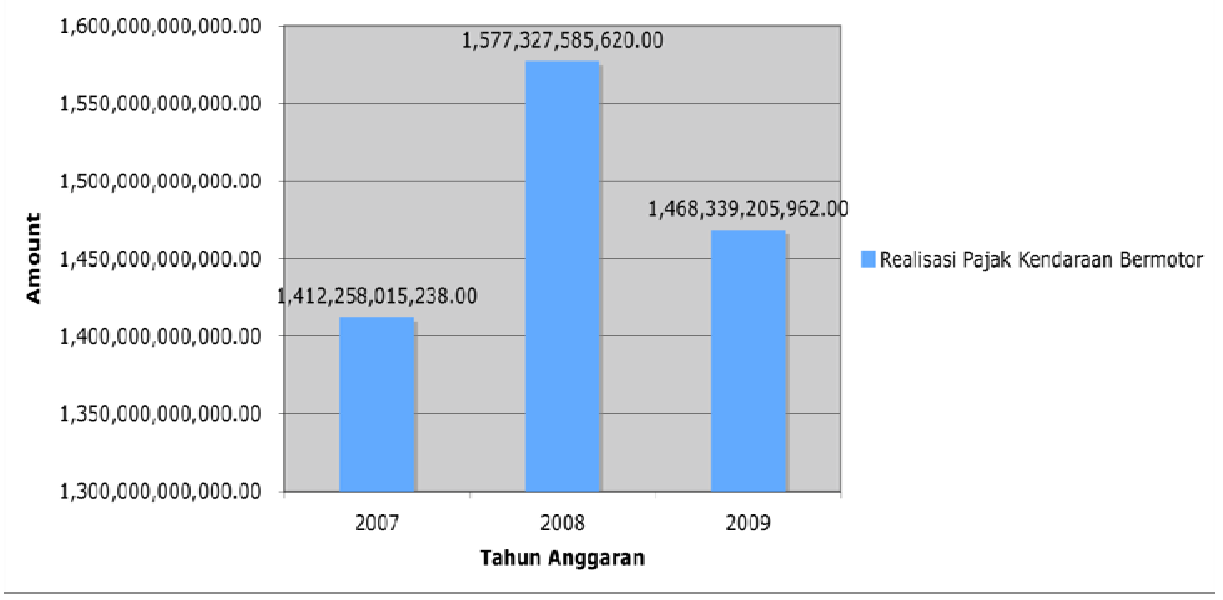

Gambar 2. Realisasi PKBJakarta (2007-2009)

Tabel 3. Pertumbuhan PKB Jakarta(2007-2009)

\begin{tabular}{lcrc}
\hline & Realisasi PKB & Pertumbuhan (Rp) & (\%) \\
\hline 2007 & $1,412,258,015,238.00$ & - & - \\
2008 & $1,577,327,585,620.00$ & $165,069,570,382.00$ & 11.69 \\
2009 & $1,468,339,205,962.00$ & $(91,339,959,426.00)$ & -6.91 \\
\hline \multicolumn{3}{c}{ Rata-rata } & 2.39 \\
\hline
\end{tabular}

Pemerintah daerah dan khususnya Samsat setiap tahunmencoba membuat perencanaan penerimaan PKB sebagai pedoman pengukuran prestasi, namun demikian ternyata dalam pelaksanaannya sering tidak memenuhi target rencana yang ada.

Dalam Perbandingan Rencana dan Realisasi Penerimaan PKB selama periode 2007-2009, diawali memperhatikan faktor subyektif dan harapan serta memotivasi pelaksanaan pengumpulan PKB, maka dibuat rencana memakai variable data statistik tahun atau periode sebelumnya, pertumbuhan ekonomi, tingkat inflasi dls. Tanpa mengkritisi bagaimana pembuatan angka rencana penerimaan PKB setiap tahun, penulis mencoba mendapatkan data dan informasi yang terbatas, untuk dipakai dalam analisa aspek perkembangan realisasi penerimaanPKB dan peranannya ke PAD dan ke APBD.

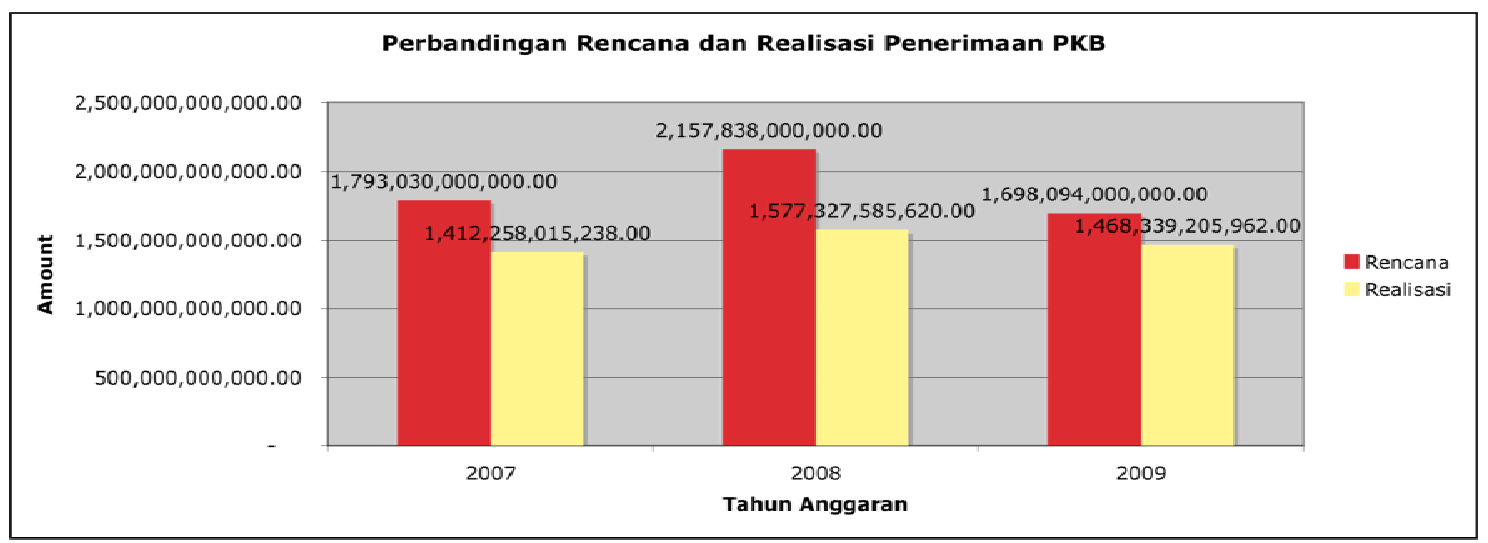

Gambar 3. Rencana dan realisasi penerimaan PKB Jakarta(2007-2009) 
Grafik tersebut menunjukkan periode 2007-2009 rencana dan realisasiKantor Samsat Jakarta Selatan tidak dapat terpenuhi. Dari informasi yang didapat, pihak Samsat menjelaskan bahwa terkadang rencana yang dibuat tidak selalu terpenuhi, karena dipengaruhi beberapa faktor, seperti kendaraan yang mutasi ke luar kota, atau WP yang biasa membayar PKBnya di Samsat Jakarta Selatan tidak lagi membayarnya di Samsat Jakarta Selatan (mutasi ke wilayah lain), atau tidak taatnya WP dalam membayarnya tepat waktu, serta kondisi ekonomi yang berubah-ubah, atau masalah teknis lain.

Tabel 4. Rencana dan Realisasi PKBJakarta(2007-2009)

\begin{tabular}{rrrr}
\hline \multicolumn{2}{c}{ Rencana } & Realisasi & Naik (\%) \\
\hline 2007 & $1,793,030,000,000.00$ & $1,412,258,015,238.00$ & 78.76 \\
2008 & $2,157,838,000,000.00$ & $1,577,327,585,620.00$ & 73.10 \\
2009 & $1,698,094,000,000.00$ & $1,468,339,205,962.00$ & 86.46 \\
\hline \multicolumn{5}{r}{ Rata-rata } & 79.44 \\
\hline
\end{tabular}

Keterbatasan prasarana pengangkutan umum masal dalam kotatermasuk Jakarta yang disediakan oleh pemerintah daerah, dewasa ini hanya terbataspada bis kota, kereta api, taksi, bajay dan angkot (dikecualikan yang hanya berbentuk roda dua atau ojek).

Tabel 5. Kendaraan Bermotor - pembayar PKB Samsat Jakarta (2007-2009)

\begin{tabular}{|c|c|c|c|}
\hline & KB (PKB) & KB (BBN.KB) & Total \\
\hline 2007 & $1,038,218$ & 216,021 & $1,254,239$ \\
\hline 2008 & $1,020,587$ & 228,563 & $1,249,150$ \\
\hline 2009 & $1,049,277$ & 207,231 & $1,256,508$ \\
\hline
\end{tabular}

Tabel 5 menunjukkan jumlah kendaraan yang membayar PKBdi Samsat Jakarta Selatan yang mengalami naik dan turun. Ini sebagai salah satu faktor penyebab rencana dan realisasi dari PKB di Samsat Jakarta Selatan tidak selalu tercapai. Terlihat ditabel, rencana 2008 dibuat terlalu tinggi, tetapinyatanya jumlah kendaraan 2008 justru menurun, padahal 2008 sudah didukung Samsat Keliling, itu juga salah satu faktor rencana PKB 2008 terlalu tinggi. Samsat Keliling diharapkan dapat menambah hasil penerimaan dari PKB tetapi kenyataannya tidak, sedang pada 2009 memang mengalami kenaikan tetapi tidak cukup besar. Pada Tabel 5 tersebut terlihat rencana dibuat tidak setinggi 2008, namun tetap saja tidak dapat terrealisasi padahal dalam 2009 sudah ada program baru selain Samsat Keliling, yaitu drive-thru.

Jumlah kendaraan yang melaporkan pajaknya pada Samsat Jakarta Selatan ternyata pertumbuhan2007-2009 tidak terlalu signifikan. Inisebagai salah satu penyebab rencana dan realisasi penerimaan PKB Samsat Jakarta Selatan tidak tercapai, disamping kendala lain yang diulas sebelumnya. Adanya kebocoran dalam pelaksanaan pemungutan/pembayaran PKB mungkin masih bisa terjadi, namun ke depan hal itu akan bertahap dan segera berkurang sejalan dengan semangat reformasi dan perbaikan sistim administrasi terutama dengan pemakaian teknologi informasi.

\section{Peranan Pajak Kendaraan Bermotor terhadap Pajak Daerah}

PKB adalah salah satu penerimaan Pajak Daerah yang dapat memberi peran cukup besar 30\%40\% dalam penerimaan Pajak Daerah Propinsi DKI Jakarta untuk membiayai pembangunan dan memajukan daerah. Terlihat dalam Tabel 6 perbandingan kedua variabel tersebut. 


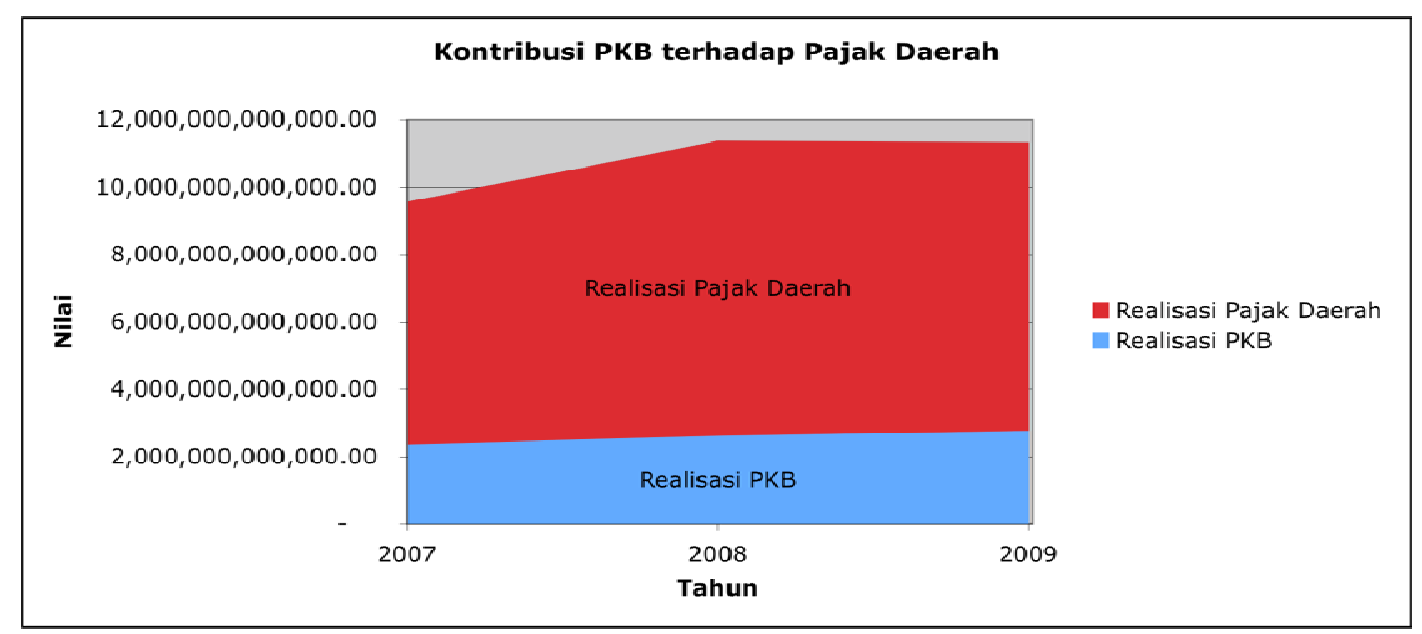

Gambar 4. Peranan PKB terhadap Pajak Daerah DKI Jakarta

Tabel 6. Peranan PKB terhadap Pajak Daerah DKI Jakarta (2007-2009)

\begin{tabular}{|c|c|c|c|}
\hline & si PKB (Rp) & Realisasi Pajak Daerah (Rp) & $\%$ \\
\hline 2007 & $2,368,877,005,505.00$ & $7,203,335,432,543.02$ & 32.89 \\
\hline 2008 & $2,618,745,860,159.00$ & $8,751,766,115,353.00$ & 29.92 \\
\hline \multirow[t]{2}{*}{2009} & $2,766,961,102,529.00$ & $8,560,062,560,145.00$ & 32.32 \\
\hline & & Rata-rata & 31.71 \\
\hline
\end{tabular}

Peranan PKB terhadap Pajak Daerah kurun 2007-2009 untuk 2007 peranan PKB pada Pajak Daerah 32,89\% danpada 2008menurun menjadi 29,92\% (turun 2,97\%) dari 2007. Pada 2009 meningkat menjadi 32,32\% (naik 2,40\%), hal ini mungkinkarena penerimaan Pajak Daerah mengalami penurunan dari 2008 ke 2009, sedang penerimaan PKB selalu meningkat dan dilihat dari rata-rata pertumbuhannya, dimana hampir sepertiga dari Pajak Daerah adalah dari penerimaan PKB.

Peranan penerimaaan PKB terhadap PAD relatif sulit melakukan analisa berhubung PAD mengalami pertumbuhan yang relatif konstan, namun penerimaan PKB terjadi keadaan khusus pada 2009.

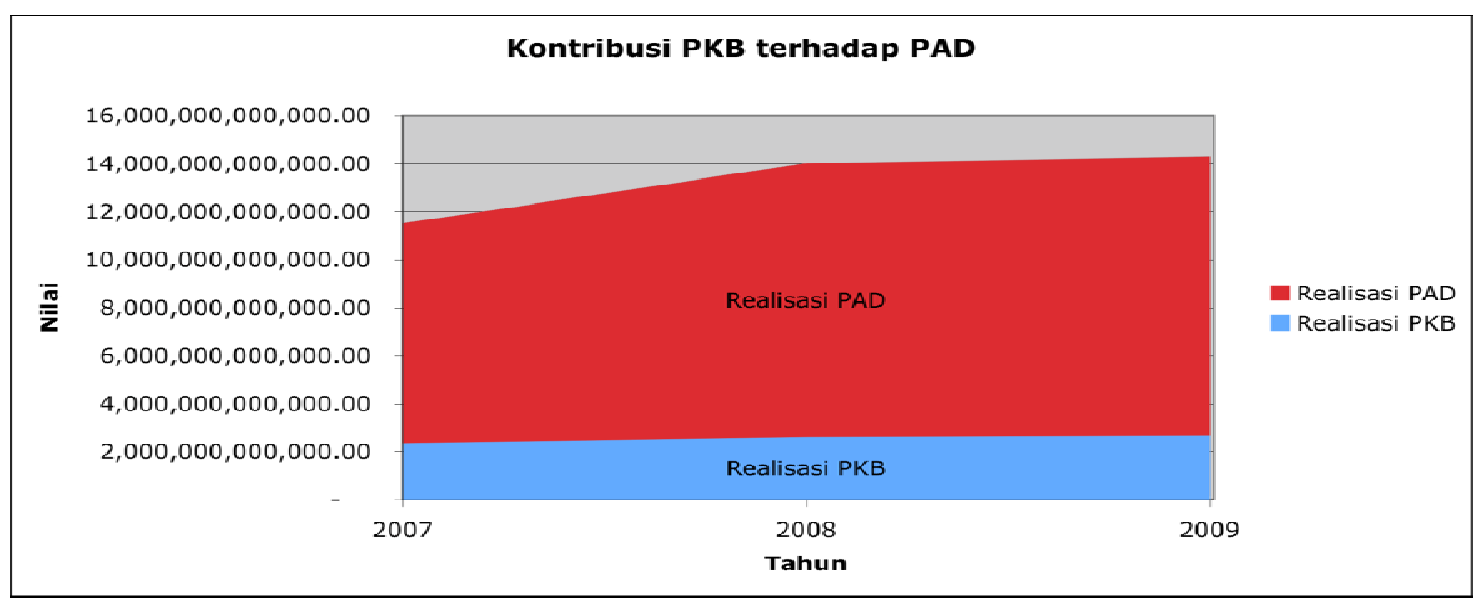

Gambar 5. Peranan PKB terhadapPAD (2007-2009) DKI Jakarta 
Dari Gambar 5 menunjukkan bahwa PKB merupakan bagian dari Pajak Daerah dan memberikan peranan yang relatif cukup besar terhadap PAD walau masih sekitar $30 \%$ namun masih lebih besar dari sumber PAD lainnya.

Tabel 7. Pengaruh PKB terhadap PAD - DKI Jakarta(2007-2009)

\begin{tabular}{lrrr}
\hline & Realisasi PKB (Rp) & Realisasi PAD (Rp) & $\%$ \\
\hline 2007 & $2,368,877,005,505.00$ & $9,143,085,836,048.00$ & 25.91 \\
2008 & $2,618,745,860,159.00$ & $11,397,575,296,977.00$ & 22.98 \\
2009 & $2,687,000,000,000.00$ & $11,626,720,253,115.20$ & 23.11 \\
\hline \multicolumn{3}{c}{ Rata-rata } & 24.00 \\
\hline
\end{tabular}

Pengaruh PKB terhadap PAD kurun tiga tahun terakhir mengalami naik turun, dari $2007=$ 25,91\% dan pada 2008 turun menjadi 22,98\% (turun 2,93\%). Hal ini terjadi karena pada 2008, PAD mengalami peningkatan cukup tinggi sedang PKB peningkatannya tidak terlalu tinggi.Pada 2009 mengalami sedikit meningkat menjadi 23,11\% (naik 0,13\%). Dengan rata-rata pertumbuhan 24\% dalam tiga tahun, peranan PKB terhadap PAD cukup bagus dibanding kontribusidari sumber pendapatan lain.

\section{PENUTUP}

Dewasa in pertumbuhan jumlah kendaraan bermotor (khususnya roda dua) di kota besar terutama Jakarta telah meningkat drastis, melewati pertumbuhan sarana prasarana yang ada. Kondisi tersebut dilandasi dengan peningkatan ekonomi nasional dan kesejahteraan sebagian penduduk, yang ternyata telah berakibat dengan kemacetan jalan. PKB menjadi sumber penerimaan Pajak Daerah paling dominan peranannya terhadap PAD, sebagai primadona bagi pemasukkan Pajak Daerah. Dominasi peranan PKB tersebut selain ditunjang oleh potensi yang cukup besar juga sangat bergantung pada mutu pelayanan, efektivitas pelaksanaan sistem pemungutan yang dilakukan melalui Samsat. Dalam mewujudkan sistem pelayanan yang baik perlu dilakukan segala upaya optimalisasi pelaksanaan pemungutan PKB secara progresif oleh Dinas Pendapatan Daerah (Dipenda) bersama Kantor Samsat. Upaya tersebut umumnya adalah lebih meningkatkan pengawasan dan pendekatan intensifikasi penagihan dan ekstensifikasi serta upaya secara persuasif untuk sosialisasi kepada masyarakat, mengingatkan kewajiban pembayaran PKB dan peningkatan pelayanan lain.

Samsat Keliling (Samling) merupakan upaya atau kegiatan untuk lebih mendekatkan pelayanan kepada masyarkat.Pelaksanaan ini baru disosialisasikan pada 2007 dan berjalan efektif pada 2008. Pelaksanaan kegiatan ini berada pada lokasiyang mudah dijangkau masyarakat di lima wilayah Propinsi DKI Jakarta. Sarana atau fasilitas yang ada berupa sebuah bisdengan seperangkat komputer on-line tersambung dengan alat switch dan router, khusus untuk pembayaran $\mathrm{PKB}$, sedang untuk mekanisme pelaksanaan pemungutan PKB pada Samling saat melayani pelayanan pengesahan STNK dan perpanjanganSurat Ijin Mengemudi (SIM). Kegiatan ini bertujuan untuk memudahkan masyarakat wajib bayar PKB untuk melaksanakan kewajiban pajaknya tanpa harus datang ke Samsat, dilaksanakan tiap hari kerja selama seminggu Samling akan berada di tempat yang telah ditentukan (Perubahan tempat $=1 \mathrm{x}$ seminggu). Jadwal Samling dapat mudah diakses internet-website Ditlantas Polda Metro. Upaya sistem pelaksanaan ini dinilai dapat menunjang peningkatan penerimaan PKB, apalagi bila jumlah bis, lokasi dan jam pelayanannya ditambah lagi (termasuk hari libur dan Sabtu).

Drive-thru merupakan inovasi pelayanan mulai 2009 oleh Pemerintah Daerah DKI Jakarta bagian Dinas Pelayanan Pajak khususnya Kantor Samsat yang berfungsi mendekatkan pelayanan pajak kepada WP, memberikan pelayanan cepat bagi pembayar PKB. Layanan drive-thruselama jam kerja ini baru berada di wilayah Samsat Jakarta Selatan dan hanya melayani kendaraan roda empat 
saja. Mulai 2010 layanan drive-thru sudah ada di seluruh Samsat Jakarta dan dapat melayani kendaraan roda empat dan roda dua, dengan keunggulan layanan cepatnya proses pembayaran PKB ( \pm 5 menit) tanpa turun dari kendaraan. Upaya sistem pelaksanaan ini dinilai dapat menunjang peningkatan penerimaan PKB, apalagi bila jumlah tempat, lokasi dan jam pelayanannya ditambah lagi (termasuk hari libur dan Sabtu).

Meningkatnya penerimaan PKB Propinsi DKI Jakarta Raya, maka akan makin memberikan pengaruh besar terhadap PAD Propinsi, sehingga dengan adanya upayaoptimalisasi tersebut diharapkan dapat terus meningkatkan penerimaan PKB tiap tahun dan upaya tersebut dilakukan juga untuk meningkatkan PAD. Penerimaan PKB memberikan pengaruh besar kepada Pajak Daerah dan PAD dengan tujuan dapat membiayai penyelenggaraan pembangunan daerah di Propinsi DKI Jakarta, walaupun semakin meningkatnya jumlah kendaraan bermotor di DKI Jakarta yang akan menyebabkan kemacetan. Tujuan utama pemungutan PKB dalam penelitian ini adalah untuk turut membantu dalam perkembangan Propinsi DKI Jakarta.

Pembayaran PKB adalah menjadi kewajiban untuk dibayar oleh WP pemilik atau pengguna kendaraan bermotor, sehingga pada akhirnya akan mengurangi keuangannya. Disamping pemerintah daerah yang telah dan/atau akan terus berusaha memperbaiki sistim pelayanan transportasi untuk masyarakat termasuk Bus way, Samsat Keliling dan Drive-thru, maka pemerintah daerah akan mencoba memakai peranan pajak daerah yang terkait dengan kendaraan bermotor untuk mengatur pemecahan masalah transportasi yang terjadi, termasuk pelaksanaan penegakan hukum, terutama penerapan pajak progresif, ERP (Elektronic Road Pricing), dan Electronik Ticketing, serta pembatasan pemakaian BBM bersubsidi atau pemakaian nomor mobil ganjil/genap.

Dewasa ini pemerintah DKI juga pernah mencoba pembuatan monorail yang perkembangannya masih tertunda dengan negosiasi dengan pihak investor dari luar negeri. Sedangkan bus-way sudah sebagian besar berjalan dengan segala kelemahan dan masalahnya, namun dianggap cukup berhasil sedikit mengurai kemacetan di jalan. Pembatasan parkir parallel di sebagian jalan tertentu (Gajahmada - Majapahit) perlu diperluas ke jalan protokol lainnya dengan dampak positif lain, mendorong pembangunan gedung parkir bertingkat oleh pihak swasta.

Terobosan penting dalam rangka penegakan disiplin adalah pelaksanaan Elektronic ticketing, dimana sedangatau telah pernah diuji coba di salah satu jalan utama (jalan MH Thamrin), dengan segala kendalanya perlu terus dikembangkan ke jalan utama lain di DKI. Pelaksanaan sistim Three-inone, akan dikaji ulang selain kurang efisien/efektif, ternyata dapat menimbulkan dampak lain dalam kemacetan yakni aspek kependudukan dan kemacetan yang timbul saat mobil berhenti dan joki naik/turun mobil. Pemikiran menggantikan three-in-one adalah menerapkan sistem ERP (Electronic Road Pricing) yang sudah berhasil dilakukan di beberapa Negara lain.

Selama jam sibuk di beberapa jalur busway akan diberlakukan ERP, dan sudah ada beberapa investor siap bersedia untuk membiayainya. Terkait pelaksanaan ERP ini, terdapat banyak pihak yang menginginkan sugera dibuat dan diputuskan pengaturan/SOP dana yang akan diterima/masuk.Mereka berpendapat bahwa penerimaan uang hasil ERP sebaiknya tidak digabung dalam APBD, tetapi terpisah untuk dikembalikan ke daerah otonomi dan bisa dipakai untuk suatu sistim yang bisa lebih mendorong mengurai kemacetan pada jam sibuk termasuk di Jakarta.

Dari beberapa opsi tersebut, sebagai upaya yang relatif mudah dan murah adalah pelaksanaan Tarif PKB progresif yang sudah dilaksanakan mulai 2011, sebagai upaya agar tidak terlalu banyak (pembatasan) kepemilikan kendaraan bermotor (dengan alamat tempat tinggal sama). Keberhasilan upaya terakhir ini perlu sosialisasi gencar dan memantau perkembangannya dan segera menyelesaikan kendala yang muncul. 
Bersama kebijakan terkait kendaraan bermotor yang lain, secara administrasi akan juga meningkatkan penerimaan jenis pajak daerah lainnya (BBN KB), namun perlu terus disempurnakan sistim BBN KB tersebut. Berhubung segala opsi upaya mengurai kemacetanakan menyebabkan penerimaan uang relatif besar, maka perlu aturan tentang pemanfaatan dana yang terkumpul/masuk, yang seharusnya untuk perbaikan sarana prasarana terkait transpormasi \& Kendaraan bermotor.

Untuk lebih efektif/efisien upaya penguraian kemacetan transportasi, mungkin perlu diperhatikan aspek Pajak Parkir dan penyesuaian bertahap tarif PKB progresif agar lebih progresif (sesuai UU maksimal 10\%), maka perlu ditinjau/disesuaikan setiap 1-2 tahun. Kebijakan penunjang selain upaya sosialisasi ke WP, juga pendidikan para pengemudi dan pemakai jalanterkait peraturan dan norma (how to be good drivers = driving manners). Pengetahuan, kesadaran, dan kepedulian pemakaian jalan umum untuk keselamatan dan kenyamanan bersama diperlukan sebelum pemberian SIM, dan secara periodik oleh Dinas Perhubungan (Pemerintah Daerah) dan atau pihak swasta setiap sepuluh tahun. Sosialisasi dilakukan setiap hari melalui media cetak atau elektronik dan dilakukan secara aktif / pasif serta langsung/tidak langsung (website).

Perlu diantisipasi juga laju pertumbuhan kepemilikan kendaraan bermotor tahun-tahun mendatang, mengingat statistik selama ini ternyata menurut sumber Gaikindo (Bisnis Indonesia, 11 Juli 2011), sejak 2007 secara rata-rata menanjak kecuali 2009 dengan jumlah pasar ritel nasional adalah 436.052 (2007), 596.151 (2008), 488.908 (2009), 745.390 (2010), dan ditargetkan 830.000 (2011). Dengan penerapan tarif PKB progresif, diharapkan dapat mengurai kemacetan jalan karena pengurangan pemilikan kendaraan bermotor oleh satu keluarga (alamat sama), namun bagaimana kekuatan hukumbila mereka sebenarnya adalah subyek hukum berbeda (keluarga/rumah besar, rumah susun/apartment). Kekuatiran praktek Kartu Tanda Penduduk (KTP) palsu dengan alamat fiktif, mungkin terjawab dengan pelaksanaan e-KTP.Semua kebijakan tersebut akan lebih berhasil bila sudah ada sarana transportasi masal (seperti termasuk bis bertingkat, monorail, fly-over, subway).

Terdapat hambatan dan atau kendala penerapan tarif PKB progresif, pertama WP sendiri yang dihadapkan opsi mengikuti aturan dengan pembatasan pemilikan kendaraan bermotor, atau terpaksa alokasikan dana lebih untuk pembayaran PKB progresif jika memiliki kendaraan bermotor beberapa buah. Dunia bisnis juga menentang kebijakan progresif PKB tersebut, sebab dikuatirkan akandapat menurunkan tingkat penjualan, produksi, dan kemampuan penyerapan tenaga kerja (isu makro/nasional).Mereka lebih berkepentingan dengan aspek mikro, bukan aspek makro secara nasional.

\section{DAFTAR PUSTAKA}

Darwin. (2010). Pajak daerah dan retribusi daerah. Mitra Wacana Media.

Mardiasmo. (2008). Perpajakan. Andi.

Menterti Dalam Negeri. (2004). Peraturan Menteri Dalam Negeri Nomor 6 Tahun 2004, tentang Perubahan Keputusan Menteri Dalam Negeri Nomor 35 Tahun 2002 tentang Pedoman Alokasi Biaya Pemungutan Biaya Daerah.

Presiden Republik Indonesia. (2001). Peraturan Pemerintah Republik Indonesia Nomor 65 Tahun 2001, tentang Pajak Daerah. Jakarta: Lembaran Negara Republik Indonesia Tahun 2001 Nomor 118. 
Republik Indonesia. (2007). Undang-Undang Nomor 28 Tahun 2007 tentang Perubahan Ketiga atas Undang-Undang Nomor 6 Tahun 1983 tentang Ketentuan Umum dan Tata Cara Perpajakan. Jakarta: Lembaran Negara Republik Indonesia Tahun 2007 Nomor 85.

Republik Indonesia. (2009). Undang-undang Nomor 28 Tahun 2009 tentang Pajak Daerah dan Retribusi Daerah. Jakarta: Lembaran Negara Republik Indonesia Tahun 2009 Nomor 130.

Siahaan, M. P. (2005). Pajak daerah dan retribusi daerah. Jakarta: Raja Grafindo. 